\title{
"Business risks and their impact on business future concerning the entrepreneur's experience with business bankruptcy: case of Czech Republic"
}

Ján Dvorský (D https://orcid.org/0000-0002-6078-2636

R http:/www.researcherid.com/rid/C-9213-2018

AUTHORS

Aleksandr Ključnikov (D) https://orcid.org/0000-0003-0350-2658

R http://www.researcherid.com/rid/K-6273-2018

Jiří Polách

Ján Dvorský, Aleksandr Ključnikov and Jiři Polách (2020). Business risks and

ARTICLE INFO their impact on business future concerning the entrepreneur's experience with business bankruptcy: case of Czech Republic. Problems and Perspectives in Management, 18(2), 418-430. doi:10.21511/ppm.18(2).2020.34

DOI http://dx.doi.org/10.21511/ppm.18(2).2020.34

RELEASED ON Friday, 03 July 2020

RECEIVED ON Tuesday, 05 May 2020

ACCEPTED ON

Tuesday, 23 June 2020

\section{(c) EY}

LICENSE

This work is licensed under a Creative Commons Attribution 4.0 International License

JOURNAL

"Problems and Perspectives in Management"

ISSN PRINT $1727-7051$

ISSN ONLINE $1810-5467$

PUBLISHER

LLC "Consulting Publishing Company "Business Perspectives"

FOUNDER

LLC "Consulting Publishing Company "Business Perspectives"

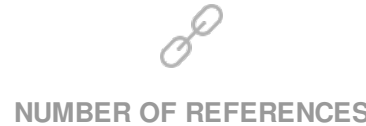

55
NUMBER OF FIGURES

1
=:-

NUMBER OF TABLES

5

(C) The author(s) 2022. This publication is an open access article. 


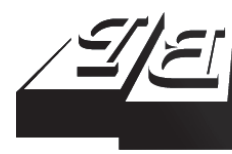

\section{BUSINESS PERSPECTIVES}

LLC "CPC "Business Perspectives" Hryhorii Skovoroda lane, 10, Sumy, 40022, Ukraine www.businessperspectives.org
Received on: $5^{\text {th }}$ of May, 2020 Accepted on: $23^{\text {rd }}$ of June, 2020 Published on: $3^{\text {rd }}$ of July, 2020

(C) Ján Dvorský, Aleksandr Ključnikov Jiří Polách, 2020

Ján Dvorský, Ph.D., Department of Business Administration, Faculty of Management and Economics, Tomas Bata University in Zlín, Czech Republic. (Corresponding author)

Aleksandr Ključnikov, Ph.D., Associate Professor, University of Entrepreneurship and Law, Czech Republic.

Jiří Polách, Ph.D., Professor, University of Entrepreneurship and Law, Institute of Entrepreneurship and Marketing, Praha, Czech Republic.
This is an Open Access article, distributed under the terms of the Creative Commons Attribution 4.0 International license, which permits unrestricted re-use, distribution, and reproduction in any medium, provided the original work is properly cited.

Conflict of interest statement: Author(s) reported no conflict of interest
Ján Dvorský (Czech Republic), Aleksandr Ključnikov (Czech Republic), Jiří Polách (Czech Republic)

\section{BUSINESS RISKS AND}

THEIR IMPACT ON BUSINESS FUTURE CONCERNING

THE ENTREPRENEUR'S EXPERIENCE WITH BUSINESS BANKRUPTCY: CASE OF CZECH REPUBLIC

\begin{abstract}
The article aims to determine the difference in the perception of selected business risks and their impact on the future of business concerning the entrepreneur's experience with business bankruptcy. The case study involved 73 small and medium-sized enterprises (SMEs) with experience of business bankruptcy and 381 SMEs without the experience of business bankruptcy from the Czech Republic (CR). Linear regression models were used to verify statistically significant causal relationships between selected indicators of the most significant business risks and respondents' perceptions of the future of business. The results brought interesting findings. The attitudes of entrepreneurs show that personnel, market, and financial risk are among the three most significant business risks. Experience with business failure is not a significant factor in determining the impact of market indicators on the business's perceived future. The adequacy of sales of services and products has the greatest impact. The experience of the bankruptcy of SMEs is important in financial risk attitudes. According to entrepreneurs who have no experience with bankruptcy, the perception of financial performance has the greatest direct impact on the future of business. Conversely, for entrepreneurs who have experienced bankruptcy, the ability to properly manage financial risk on the company's future has the greatest direct impact.
\end{abstract}

\section{Keywords}

small and medium-sized enterprises, future of the enterprise, business risks, experience with bankruptcy

\section{JEL Classification $\quad$ M21, G32, L26}

\section{INTRODUCTION}

Entrepreneurship and entrepreneurial activity is an essential engine of the economy because it reduces critical economic indicators (e.g., unemployment rate) and promotes economic growth (Lu, Gozgor, Huang, \& Lau, 2020; Hudakova \& Masar, 2018; Anwar ul Haq, Usman, Hussain, \& Anjum, 2014). Entrepreneurship is a source of social and economic profit for society. The importance of entrepreneurship and entrepreneurial activity is emphasized not only by documents at the national levels of countries but also in documents of a supra-regional nature, such as the European Commission. It highlights the contribution of SMEs to the management of the regions covering the European Union (EU). SMEs operating in the EU created more than $55 \%$ of value-added in 2018 alone and employed more than $65 \%$ of people in the EU's non-financial sector. Similar numbers can be observed in some Visegrad countries, such as Hungary and the Czech Republic (Çera, Belas, \& Zapletalikova, 2019).

These figures show why scientists, policymakers, and government have a continued interest in the "health" of SMEs. SMEs are very sus- 
ceptible to changes in the business environment, so they must be aware of their business risks. Several studies around the world say that reliable risk management ensures less negative surprises, greater financial stability of the company and provides opportunities for profit (Dvorský, Petráková, \& Polách, 2019b; Hudakova, Masar, Luskova, \& Patak, 2018).

Risk management aims to reduce the chances of an organization failing as much as possible (Kliestik, Misankova, Valaskova, \& Svabova, 2018). In this regard, it is interesting to look for the causes and consequences of closing a business in general. In this context, the identification, analysis, assessment, and management of business risks are no less important. Subsequently, policymakers and the government can modify existing policies, strategies, instruments, regulatory frameworks, etc. to improve the business environment. If there is a crisis or a time of unclear economic growth, there is a growing interest in understanding the factors that cause businesses to fail and fail (Kücher \& Feldbauer-Durstmüller, 2019).

The first section describes the results of scientific studies on the most significant business risks and acquaints the reader with the concepts of business bankruptcy and the entrepreneur's bankruptcy experience. The next section of the article presents in detail the goal of the research, methodology, and procedure of data collection obtained during the empirical research. The results and discussion present essential calculations and tests of a sample of attitudes from entrepreneurs, their economic interpretation, and a short discussion. The article concludes with the basic results of the research, its limitations, and the focus of future research.

\section{LITERATURE REVIEW}

Several authors address the causes, factors, and consequences associated with business decline. Çera, Belas, and Zapletalikova (2019), Hyder and Lussier (2016), Olaison and Sørensen (2014), Carter and Van Auken (2006) and others identify areas that, if ignored, will undoubtedly increase the likelihood of business failure. It is the lack of planning; lack of working capital; providing an excessive loan to customers; failure to implement fast outsourcing; competition in the market; monitoring corporate finances, and so on.

Many businesses begin with the idea of a product or service that seems essentially clear that it leads to business success (Inkon, 2019). Business failure may be due to insufficient understanding and business plans (Ajaz Khan, Çera, \& Nétek, 2019). All small businesses need a business plan. Even those businesses that have a business plan may fail if their plans are unworkable or based on inaccurate information (J. Yan \& L. Yan, 2016).

Experience regarding the implementation of business plans in practice tends to be different. There are business plans where owners have unrealistic expectations about income and money generation, leading to a financial crisis and business bankruptcy (Hemakumar, 2020). Other business plans focus on set-up costs but do not take into account daily operating costs (Ranasinghe, 2019). It is essential to understand that it takes a year or two for a company to establish itself in the business sector. During this period, they must secure the financial and non-financial claims of employees $(\mathrm{He}, \mathrm{Li}$, Lin, \& Liang, 2019).

All companies are trying to resell to clients, and at the same time, expect receivables to be paid on time and in full. The situation where a company went bankrupt because the company provided too favorable credit conditions is not unique (Hanzaee, Ghalandari, \& Norouzi, 2011).

Some entrepreneurs determine very early in the new business process that specific tasks can be outsourced. They believe that, on the whole, this brings significant benefits to the company (Alzhrani, 2020). However, there are problems with outsourcing that can be solved by considering some primary keys to effective outsourcing: do not be tempted to go cheap; narrowly manage the outsourcing relationship; determine critical areas that need to be outsourced and where one does not have expertise; understanding the real costs; regular communication of outputs.ne 
If one is unlucky enough to have developed a product that does not yet have a market, one will have competition in the business sector (Tipu, 2019). Failure to understand and evaluate competitors' effects (and their products and prices) harms your business model and outcome. In this context, the managerial experience of the owner/manager of the company also comes to the fore. Disadvantages such as inefficient use of time (Ajilchi \& Kargar, 2015); lack of organization of employees and processes; lack of owner/manager motivation (Murnieks, Klotz, \& Shepherd, 2020; Benzing, Chu, \& Kara, 2009; Belas, Dvorsky, Kozubikova, \& Cepel, 2019); insufficient attention to detail (Bolshakov \& Chincarini, 2020) or insufficient communication experience are also causes of business decline (Lenz, 2019).

Business owners often focus attention and initial attempts on developing and selling their products and services without tracking expenses (Durica, Valaskova, \& Janoskova, 2019). Accounting often receives secondary attention, although it should be the basis for running an efficient business (Brozyna, Mentel, \& Pisula, 2016).

Other authors pay attention to inefficient spending of funds on marketing, the extremely rapid growth of the company in the form of excessive trading (Santisteban \& Mauricio, 2017), incorrect management and leadership of the company (As. Singh \& Aj. Singh, 2020), or insufficient differentiation of their products or services.

Stepanová (2019) analyzed the distribution of companies' risk and stability on a sample of 327,000 companies in the Czech Republic. Her findings are significant. The business base analysis showed that roughly the fifth company based in the South Moravian Region and every sixth company with a Prague address are at risk of bankruptcy. These regions have the largest share of companies with a scoring grade of "risky" (CCC, CC, and C) or "bankruptcy" (D) - in the South Moravian Region (19\%) and Prague (17\%). "The largest concentration of risky companies is from Prague and around Brno. This is also because most companies do business here, which provides entrepreneurs with a greater degree of anonymity than less populated areas. The share of risky companies is around the metropolis, compared to the rest of Slovakia. In Slovakia, one in six companies is at risk of bankruptcy, according to an analysis of 217,563 companies (Bisnode, 2019).

Eklund, Levratto, and Ramello (2020) clarify the relationships between corporate failure, bankruptcy, and consequences. The authors point out that the skills that entrepreneurs can bring to new business are beneficial. Estrin, Mickiewicz, and Rebmann (2017) compared the bankruptcies of SMEs among 15 developed OECD countries that note the more difficult situation of entrepreneurs in obtaining loans. In this context, national laws and government influence play an essential role (Aidis, Estrin, \& Mickiewicz, 2012).

\section{AIM, METHODOLOGY, AND DATA}

The article aims to discover the differences in the perception of the most significant business risks and their impact on the future of business concerning the entrepreneur's experience with business bankruptcy.

Data collection took place from $09 / 2019$ to $03 / 2020$ (the period before the outbreak of the COVID-19 epidemic). The respondents are entrepreneurs (owners or senior managers) of small or medium enterprises (SME) operating in the Czech Republic's business environment. The "Cribis" database was used to define the basic set of respondents and then contact them, with feedback from respondents by completing an online questionnaire, and companies contacted by telephone to provide information on how to complete the questionnaire request.

The questionnaire is currently available on the Internet at the following link: https://forms.gle/ okjZypAru4BpSHFb8

The questionnaire consisted of 77 questions divided into several parts. In the first part of the survey, the basic characteristics of the respondent and the company were found. The second part contained statements about management, corporate social responsibility, marketing, social media, and business internationalization. The third part contained allegations concerning business risks. The fourth part of the questionnaire examined the 
respondents' attitudes to the claims regarding the bankruptcy of the company. The fifth part focused on the causes of the company's bankruptcy and risk management. The total number of SMEs contacted was 8,250 . The return rate of the completed questionnaire was at the level of 5.5\%. The claims were formulated into statements to which the respondents could answer in one of the following ways: (A1) strongly agree, (A2) agree, (A3) neither agree nor disagree, (A4) disagree, (A5) strongly disagree.

The total number of questionnaires collected was 465 SMEs. The number of correctly completed questionnaires (from now on referred to as the sample) represented 454 (97.6\%) respondents. The number of incorrectly completed questionnaires represented 11 (2.4\%) respondents. The most important reasons for excluding a respondent from the sample: duplication of the questionnaire in the sample; consistency of the respondent's attitudes to the assessment of business risks; the respondent's inattention when filling in the questions to which the respondent did not have to answer and so forth. The allegations of business risks and bankruptcy were formulated in a positive way to maintain the continuity of responses.

The following statements about business risks and statements about the company's emotional future were formulated to achieve the main goal of the article.

\section{Market risk (MR) claims:}

- MR1: I rate the market risk (lack of sales for my company) as adequate.

- MR2: Business competition motivates me to perform better.

- MR3: Selling products and services on the market is challenging. However, our company has adequate sales volume.

- MR4: Our company uses innovative ways to win new markets and retain existing customers.

\section{Financial risk claims (FR):}

- FR1: I consider financial risk as part of everyday business.

- FR2: I evaluate the financial performance of our (my) company positively.

- FR3: I understand the most crucial aspect of financial risk.
- FR4: I can adequately manage the financial risk in my (our) company.

Personnel risk claims (PER):

- PER1: Personnel risk in the company is considered adequate and does not harm my business. PER2: Employee turnover is low and has no negative impact on my business.

- PER3: The error rate of employees is low and has no negative impact on my (our) business.

- PER4: Our employees strive to improve their performance and competition among them prevails

Emotional future of business $(\mathrm{Y})$ : There is no risk of bankruptcy for our (my) company within five years.

H: $\quad$ Claims about the three most significant business (Ha: market risk; Hb: financial risk; $H c$ : personal risk) risks have an effect on the future of business according to the entrepreneur's experience with business bankruptcy in the business environment of SMEs in the CR.

Applying regression analysis in many scientific and professional types of research predicts a dependent variable in the future (Nava, Di Matteo, \& Aste, 2018). However, applying regression analysis may not always be the primary goal. Regression analysis can also be used to identify and quantify independent variables (selected business risks) and to determine the direction and strength of the impact on the dependent variable (threat of bankruptcy within five years). This second way of using regression analysis is no less important and used in practice (see more, e.g., Dvorský, Petraková, Çera, \& Folvarčná, 2019a). Since all examined variables (independent, dependent) are identical metrics (same scaling of responses), it is possible to use the statistical method to evaluate the hypothesis formulated above.

To apply regression analysis, however, certain assumptions about independent variables must be met. Independent variables must prove the assumptions of linearity, normal distribution (so-called normality), and homoscedasticity. Also, the resulting regression model must not be affected by multicollinearity, and also the random component of the time series 
produces white noise (Spanos \& McGuirk, 2002; Goodman, 1970). Verification of the above assumptions is the basis for verifying the regression model coefficients. The assumption of linearity was verified by graphical analysis of the data using a scatter plot (Hair, Anderson, Babin, \& Black, 2010; de Waal, 1977). The assumption of a normal distribution of respondents' attitudes (for an individual statement on business risks) was verified by

a) subjective evaluation (graphical analysis comparison of the histogram with the normal distribution curve);

b) calculating and testing descriptive characteristics (skewness (S) and kurtosis (K)).

If the value of skewness and the value of kurtosis was in the range of -2 to 2 , then the assumption of a normal distribution is accepted (James, 1964). A correlation matrix with pairwise correlation coefficients was used to determine the relationship between the dependent variable and the independent variables. The correlation coefficient (R) can take values from -1 to 1 (Lancaster \& Hamdan, 1964). If the correlation coefficient takes the value 1 , one speaks of a direct dependence between two variables (Hair, Anderson, Babin, \& Black, 2010). Student's t-test is applied to prove the significance of regression coefficients of independent variables. The regression coefficient in the regression model is statistically significant if the $p$-value of the $t$-test is lower than the level of significance (Zheng \& Yu, 2015). In the economic sciences, calculations are mostly used with a $5 \%$ probability of first-degree error (significance level $-\alpha=0.05)$ (Newcombe, 1998; Qin \& Lawless, 1995).

The linear regression model (RM1) has the following form:

$$
\begin{aligned}
& Y=\beta_{0}+\beta_{1} \cdot M R 1+\beta_{2} \cdot M R 2+ \\
& +\beta_{3} \cdot M R 3+\beta_{4} \cdot M R 4+\varepsilon_{n},
\end{aligned}
$$

where $Y$ - the dependent variable (perceived future of business by respondents); $\beta_{0}$ - constant, $\beta_{1}$; $\ldots ; \beta_{4}$ - coefficients of independent variables; $M R_{1}$, ..., $M R_{4}$ - independent variables $(i=1, \ldots, 4$ - strategic risk claim); $\varepsilon_{n}$ - error term.

By analogy, it is possible to create an LRM for other types of business risks ( $R M 2: F R, \ldots, R M 3: P E R$ ),
$A$ - no experience with business bankruptcy, $B$ business bankruptcy experience.

The quality of the regression model is determined by calculating and interpreting regression characteristics such as multiple correlation coefficient (MCC), determination coefficient $\left(R^{2}\right)$, adjusted determination coefficient (adj. $R^{2}$ ), F-ratio, multicollinearity, error normality (Breslow, 1990). The coefficient of determination shows the percentage explanation of the variability of the dependent variable, which can be explained by the chosen regression model (Lancaster \& Hamdan, 1964). The value of the determination coefficient is approximately the same as the adjusted coefficient of determination (adj. $R^{2}$ ) for large samples (more than 100). The F-test was used to verify the statistical significance of the entire regression model (de Waal, 1977). The F-test's required $p$-value must be lower than the level of significance if one wants to claim that the regression model is statistically significant. One proves the assumption of multicollinearity in the regression model using the variation factor of inflation (VIF test) (Liao et al., 2012). With the VIF test's value for the independent variable less than 5 , this coefficient is not affected by multicollinearity (Salmerón et al., 2018; Stewart, 1987). The Shapiro-Wilk test (S-W test) was applied to verify the normal distribution of errors (de Waal, 1977). This assumption of the regression model is accepted when the p-value of the S-W test criterion is higher than the significance level (DelićZimić \& Destović, 2019). The Bartlett's test was used to verify the assumption of homoscedasticity. This assumption is accepted with the $p$-value of the Bartlett's test criterion higher than the significance level (Snedecor \& Cochran, 1989).

Basic evaluation of questions dealing with the characteristics of the enterprise and the respondent: Size of the enterprise: $23.6 \%$ small enterprise, $63.9 \% \mathrm{mi}-$ cro enterprise, $12.5 \%$ medium enterprise; Duration of the company in the business environment: 5.9\% business up to 3 years, $6.2 \%$ business from 3-5 years, $14.1 \%$ business from $6-10$ years, $73.8 \%$ business over 10 years; Respondent's highest level of education: $10.1 \%$ secondary school without GCSE, $40.8 \%$ secondary school with GCSE, 7.5\% bachelor's university education, $37.0 \%$ master's/engineering university education, $4.6 \%$ doctoral university education; gender of respondent: $71.1 \%$ male, $28.9 \%$ female; age of respondent: $15.2 \%$ age up to 35 years, $23.3 \%$ age from 
$36-45$ years, $26.9 \%$ age from 46 to 55 years, $34.6 \%$ age more than 55 years; the relationship of education to the national economic sector: $37.7 \%$ yes, I run a business in the field I studied, $34.8 \%$ to some extent related (some business processes are related to the area I studied), 27.5\% unrelated; respondent's job position in the company: $22.0 \%$ I am the owner of the company; $78.0 \%$ I am a manager.

\section{RESULTS}

Before proceeding with the assessment of business risks according to the chosen criterion, attention is focused on identifying the most significant business risks. The respondent had the opportunity to identify a maximum of three business risks, which he perceives as the most significant in his business activities. Since the following statements about business risks did not influence the respondent, the questionnaire was conceived as the first in the section that dealt with the respondents' attitudes to business risks. Figure 1 evaluates the absolute and relative number of respondents who consider this type of business risk one of the three most significant risks.

The total number of marked options was 1,362 responses (454 - the number of respondents and three options). Respondents in total gave 1,045 answers (76.7\%). These results show that respondents used the opportunity to indicate several options in the object question. The results of the respondents show that the three most significant risks include (listed in descending order): personnel risk - 308 out of 454 respondents (67.8\%); market risk - 267 of 454 respondents $(58.8 \%)$ and financial risk - 162 of 454 respondents $(35.7 \%)$. Only 71 respondents $(15.6 \%)$ consider operational risk as one of the three most significant risks.
The results of the comparison of respondents according to the criterion (experience with bankruptcy) are (YES/NO): strategic risk - 12/74 (16.4\%/19.4\%); market risk - 46/221 (63.0\%/58.0\%); financial risk - 33/129 (45.2\%/33.9\%); personnel risk - 44/264 (60.3\%/69.3\%); legal risk - 28/1333 $(38.4 \% / 34.9 \%)$ and operational risk - 14/57 (19.2\%/15.0\%). The largest percentage difference between selected groups of respondents is in the designation of financial risk (more than 11\%).

The basic descriptive characteristics of business risk indicators (mean, standard deviation, skewness, and sharpness) are summarized in Table 1.

Table 1. Selected descriptive characteristics of the assessment of business risk claims according to the criterion

Source: Own research

\begin{tabular}{|c|c|c|c|c|c|c|c|c|}
\hline \multicolumn{9}{|c|}{ Descriptive characteristics } \\
\hline & \multicolumn{4}{|c|}{$\begin{array}{c}\text { Business bankruptcy } \\
\text { experience }\end{array}$} & \multicolumn{4}{|c|}{$\begin{array}{l}\text { No experience with } \\
\text { business bankruptcy }\end{array}$} \\
\hline & ME & SD & $S$ & $K$ & ME & SD & $S$ & K \\
\hline \multicolumn{9}{|c|}{ MR } \\
\hline$M R 1$ & 2.932 & 1.171 & -.506 & .457 & 2.367 & 1.982 & 2.228 & 2.549 \\
\hline MR2 & 2.315 & 1.141 & -.168 & .731 & .049 & .050 & .047 & 0.056 \\
\hline MR3 & 2.425 & 1.053 & -.158 & .534 & .966 & .975 & .916 & 1.086 \\
\hline MR4 & 2.644 & 1.085 & -.234 & .356 & .110 & .789 & .255 & -.568 \\
\hline \multicolumn{9}{|c|}{ FR } \\
\hline$F R 1$ & 1.877 & .927 & .508 & .896 & 1.950 & .050 & .973 & .939 \\
\hline FR2 & 2.644 & 1.251 & -.641 & .538 & 2.152 & .047 & 911 & .355 \\
\hline FR3 & 1.959 & 0.889 & 0.403 & .692 & 1.966 & .046 & .892 & .708 \\
\hline FR4 & 2.137 & .887 & 1.395 & .830 & 2.118 & .047 & .911 & .525 \\
\hline \multicolumn{9}{|c|}{ PER } \\
\hline$\overline{P E R 1}$ & 2.781 & 1.096 & -.091 & .712 & 2.659 & .059 & 1.149 & -.671 \\
\hline PER2 & 2.548 & 1.259 & -.469 & .619 & 2.407 & .064 & 1.242 & -.72 \\
\hline PER3 & 2.548 & 1.119 & -.083 & .611 & 2.310 & .057 & 1.104 & -.272 \\
\hline PER4 & 2.712 & 1.148 & -.405 & .365 & 2.751 & .059 & 1.158 & -.733 \\
\hline
\end{tabular}

Note: $M E$ - mean; SD - standard deviation; $S$ - skewness; $K-$ kurtosis.

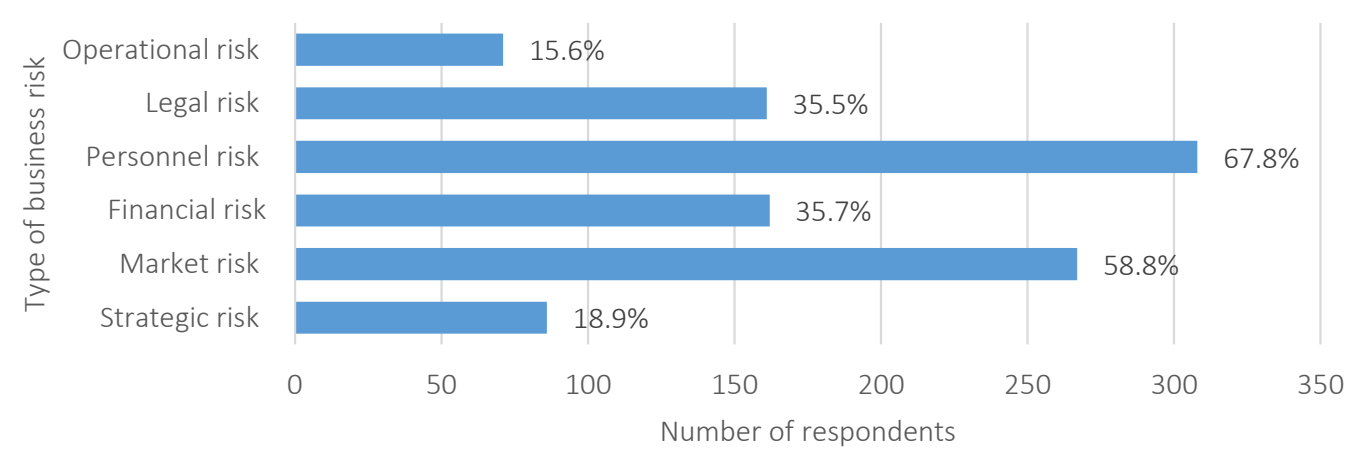

Figure 1. The most significant business risks according to the attitudes of the respondents 
Table 2. Dependences of indicators of the most significant business risks on the perceived future of business according to the criterion

Source: Own research.

\begin{tabular}{|c|c|c|c|c|c|c|c|c|c|c|c|}
\hline \multirow{3}{*}{ CM1 } & \multicolumn{10}{|c|}{ Respondent's experience with business bankruptcy } & \\
\hline & & & NO & & & \multirow{2}{*}{ CM2 } & \multicolumn{5}{|c|}{ YES } \\
\hline & $\mathbf{Y}$ & MR1 & MR2 & MR3 & TR4 & & $\mathbf{Y}$ & MR1 & MR2 & MR3 & MR4 \\
\hline Y & 1 & - & - & - & - & Y & 1 & - & - & - & - \\
\hline$M R 1$ & .204 & 1 & - & - & - & $M R 1$ & .525 & 1 & - & - & - \\
\hline$M R 2$ & .060 & .161 & 1 & - & - & $M R 2$ & .372 & .276 & 1 & - & - \\
\hline$M R 3$ & .192 & .271 & .249 & 1 & - & $M R 3$ & .360 & .565 & .558 & 1 & - \\
\hline MR4 & .060 & .113 & .216 & .170 & 1 & MR4 & .218 & .418 & .328 & .390 & 1 \\
\hline \multirow{2}{*}{ CM3 } & \multicolumn{5}{|c|}{ NO } & \multirow{2}{*}{ CM4 } & \multicolumn{5}{|c|}{ YES } \\
\hline & $Y$ & FR1 & FR2 & FR3 & FR4 & & $Y$ & FR1 & $F R 2$ & FR3 & FR4 \\
\hline$Y$ & 1 & - & - & - & - & $Y$ & 1 & - & - & - & - \\
\hline$F R 1$ & .001 & 1 & - & - & - & $F R 1$ & .077 & 1 & - & - & - \\
\hline$F R 2$ & .335 & .181 & 1 & - & - & $F R 2$ & .414 & .014 & 1 & - & - \\
\hline$F R 3$ & .164 & .207 & .346 & 1 & - & FR3 & .344 & .398 & .386 & 1 & - \\
\hline$F R 4$ & .142 & .108 & .397 & .701 & 1 & FR4 & .459 & .359 & .508 & .747 & 1 \\
\hline \multirow{2}{*}{ CM5 } & \multicolumn{5}{|c|}{ NO } & \multirow{2}{*}{ CM6 } & \multicolumn{5}{|c|}{ YES } \\
\hline & $Y$ & PER1 & PER2 & PER3 & PER4 & & $Y$ & PER1 & PER2 & PER3 & PER4 \\
\hline Y & 1 & - & - & - & - & Y & 1 & - & - & - & - \\
\hline PER1 & .058 & 1 & - & - & - & PER1 & .149 & 1 & - & - & - \\
\hline PER2 & .327 & .348 & 1 & - & - & PER2 & .060 & .571 & 1 & - & - \\
\hline PER3 & .054 & .116 & .548 & 1 & - & PER3 & .058 & .496 & .603 & 1 & - \\
\hline PER4 & .288 & .039 & .452 & .556 & 1 & PER4 & .242 & .457 & .476 & .403 & 1 \\
\hline
\end{tabular}

Note: $Y$-dependent variable; $C M$ - correlation matrix. $M R 1, \ldots, P E R 4$ - independent variables.

The assumption of a normal distribution is met for each indicator of the most significant business risks (see Table 1).

Table 2 summarizes the pairwise coefficients of correlation in the correlation matrices between the indicators of the most significant business risks and the respondents' $(Y)$ perceptions of the future of business.
Tables 3, 4, and 5 summarize the results of the verification of the statistical significance of the proposed regression models $(R M 1 A, R M 1 B, \ldots$. , RM3A, RM3B).

The results presented in Table 3 show that the $R M \mathrm{~s}$ are statistically significant $(R M 1 A$ : F-ratio ( $p$-val$\mathrm{ue})=7.3 \mathrm{E}-05 ; R M 1 B$ : F-ratio $(\mathrm{p}$-value $)=1.7 \mathrm{E}-05)$. The relationship between the company's emo-

Table 3. The influence of market risk indicators on the perception of the future of business according to the criterion

\begin{tabular}{|c|c|c|c|c|c|c|c|c|c|c|c|}
\hline \multicolumn{6}{|c|}{$R M 1 A$ - No experience with business bankruptcy } & \multicolumn{6}{|c|}{ RM1B - Business bankruptcy experience } \\
\hline MCC & \multicolumn{2}{|c|}{.249} & Adj. $R^{2}$ & & MCC & \multicolumn{2}{|c|}{.580} & Adj. $R^{2}$ & \multicolumn{2}{|c|}{.298} \\
\hline$R^{2}$ & \multicolumn{2}{|c|}{.062} & SE & \multicolumn{2}{|c|}{$\begin{array}{c}0.052 \\
1.011 \\
\end{array}$} & $R^{2}$ & \multicolumn{2}{|c|}{.337} & SE & \multicolumn{2}{|c|}{1.117} \\
\hline \multicolumn{12}{|c|}{ Verification of the significance of the entire LRM } \\
\hline ANOVA & Df & SS & MS & \multicolumn{2}{|c|}{ F-ratio } & ANOVA & Df & SS & MS & \multicolumn{2}{|c|}{ F-ratio } \\
\hline Regression & 4 & 25.46 & 6,36 & \multicolumn{2}{|l|}{6.232} & Regression & 4 & 43.10 & 10.77 & \multicolumn{2}{|c|}{8.638} \\
\hline Residual & 376 & 383.98 & 1,02 & \multicolumn{2}{|l|}{ p-value } & Residual & 68 & 84.82 & 1.25 & \multicolumn{2}{|c|}{$p$-value } \\
\hline Total & 380 & 409.44 & & \multicolumn{2}{|l|}{$7.3 \mathrm{E}-05$} & Total & 72 & 127.92 & & \multicolumn{2}{|c|}{$1.7 \mathrm{E}-05$} \\
\hline \multicolumn{12}{|c|}{ Statistical significance test } \\
\hline Variables & RC & SE & $t$-stat & $\begin{array}{c}\text { Sign. } \\
(p \text {-value })\end{array}$ & VIF & Variables & RC & SE & t-stat & $\begin{array}{c}\text { Sign. } \\
(p \text {-value })\end{array}$ & VIF \\
\hline Intercept & 1.317 & .199 & 6.622 & .000 & - & Intercept & .723 & .433 & 1.671 & .099 & - \\
\hline MR1 & 175 & .056 & 3.123 & .002 & 1.093 & MR1 & .578 & .142 & 4.074 & .000 & 1.591 \\
\hline$M R 2$ & .008 & .056 & .135 & .892 & 1.112 & $M R 2$ & .335 & .141 & 2.377 & .020 & 1.496 \\
\hline MR3 & .167 & .061 & 2.753 & .006 & 1.145 & $M R 3$ & -.078 & .176 & -.442 & .660 & 1.993 \\
\hline MR4 & .017 & .049 & .344 & .731 & 1.068 & MR4 & -.079 & .138 & -.573 & .569 & 1.300 \\
\hline
\end{tabular}

Note: Df - Degree of freedom; SS - Sum of Squares; MS - Mean of Square; RC - Regression Coefficient; SE - Standard Error. 
tional future and market risk indicators is weakly positive for $R M 1 A(M C C=.249)$ and moderately strong for $R M 1 B(M C C=.580)$. The proposed regression model $(R M 1 A)$ explains $5.2 \%$ of $Y$ variability and for $R M 1 B$ it is up to $29.8 \%$ of $Y$ variability. Statistically significant indicators of market risk in $R M 1 A$ include: $M R 1$ (t-stat: $p$-value $=.002$ ); MR3 ( $t$-stat: $p$-value $=.006)$. Statistically significant indicators of market risk in $R M 1 B$ include: $M R 1$ ( $t$-stat: $p$-value $=.000)$ and $M R 2(t$-stat: $p$-val$\mathrm{ue}=.020)$. The linear regression function for the selected $R M$ has the form:

RM1A:

$$
\begin{aligned}
& Y=1.317+0.175 \cdot M R 1+ \\
& +0.008 \cdot M R 2+0.167 \cdot M R 3+ \\
& +0.017 \cdot M R 4+\varepsilon_{t},
\end{aligned}
$$

RM1B:

$$
\begin{aligned}
& Y=0.723+0.578 \cdot M R 1+ \\
& +0.335 \cdot M R 2-0.078 \cdot M R 3- \\
& -0.079 \cdot M R 4+\varepsilon_{t},
\end{aligned}
$$

where $Y$ - dependent variable (perception of the future of business); $M R 1, \ldots, M R 4$ - independent variables (market risk indicators); $\varepsilon_{t}$ - error term.

Multicollinearity was not confirmed for either $R M$ (VIF values are higher than the critical value for both $R M 1 A$ and $R M 1 B$ ). Homoscedasticity was confirmed in both RMs (RM1A: Bartlett's test: $p$-value $=.177 ; R M 1 B$ : Bartlett's test: $p$-val$\mathrm{ue}=.233)$. The normal distribution of the deviations of the error terms in both $R M$ s was confirmed by the S-W test (RM1A: S-W test: $p$-val$\mathrm{ue}=0.148 ; R M 1 B: \mathrm{S}-\mathrm{W}$ test: $p$-value $=.225)$. The evaluation of scientific hypothesis: $H_{a}$ was accepted for both groups of respondents according to the entrepreneur's experience with business bankruptcy.

The comparison of the impact of financial risk on the perception of the future of business according to the respondent's experience with the bankruptcy of business is the subject of Table 4 .

The results presented in Table 4 show that the $R M$ s are statistically significant $(R M 2 A$ : F-ratio $(p$-value $)=6.4 \mathrm{E}-10 ; R M 2 B:=\mathrm{F}$-ratio $(p$-value $)$ $=5.4 \mathrm{E}-05)$. The relationship between the company's emotional future and financial risk indicators is weakly positive for RM2A (MCC = $.348)$ and moderately strong for $R M 2 B(M C C=$ .550). The proposed regression model $(R M 2 A)$ explains $11.2 \%$ of $Y$ variability and for $R M 2 B$ it is up to $26.2 \%$ of $Y$ variability. Statistically significant indicators of financial risk in $R M 2 A$ include: $F R 2$ ( $t$-stat: $p$-value $=.000)$. Statistically significant indicators of financial risk in $R M 2 B$ include: $F R 1$ ( $t$-stat: $p$-value $=.034)$ and $F R 4$

\begin{tabular}{|c|c|c|c|c|c|c|c|c|c|c|c|}
\hline \multicolumn{6}{|c|}{ RM2A - No experience with business bankruptcy } & \multicolumn{6}{|c|}{ RM2B - Business bankruptcy experience } \\
\hline MCC & \multicolumn{2}{|c|}{.348} & Adj. $R^{2}$ & \multicolumn{2}{|c|}{.112} & $\mathrm{MCC}$ & \multicolumn{2}{|c|}{.550} & Adj. $R^{2}$ & \multicolumn{2}{|l|}{.262} \\
\hline$R^{2}$ & \multicolumn{2}{|c|}{.121} & SE & \multicolumn{2}{|l|}{.978} & $R^{2}$ & \multicolumn{2}{|c|}{.303} & SE & \multicolumn{2}{|l|}{1.145} \\
\hline \multicolumn{12}{|c|}{ Verification of the significance of the entire LRM } \\
\hline ANOVA & Df & SS & MS & \multicolumn{2}{|c|}{ F-ratio } & ANOVA & Df & SS & MS & \multicolumn{2}{|c|}{ F-ratio } \\
\hline Regression & 4 & 49.73 & 12.43 & \multicolumn{2}{|l|}{12.994} & Regression & 4 & 38.71 & 9.68 & \multicolumn{2}{|l|}{7.376} \\
\hline Residual & 376 & 359.71 & 0.96 & \multicolumn{2}{|c|}{$p$-value } & Residual & 68 & 89.21 & 1.31 & \multicolumn{2}{|c|}{$p$-value } \\
\hline Total & 380 & 409.44 & & \multicolumn{2}{|c|}{$6.4 \mathrm{E}-10$} & Total & 72 & 127.92 & & \multicolumn{2}{|c|}{$5.4 \mathrm{E}-05$} \\
\hline \multicolumn{12}{|c|}{ Statistical significance test } \\
\hline Variables & RC & SE & t-stat & $\begin{array}{c}\text { Sign. } \\
\text { ( } p \text {-value) }\end{array}$ & VIF & Variables & RC & SE & t-stat & $\begin{array}{c}\text { Sign. } \\
(p \text {-value })\end{array}$ & VIF \\
\hline Intercept & 1.367 & .169 & 8.070 & .000 & - & Intercept & 1.455 & 0.433 & 3.359 & .001 & - \\
\hline$F R 1$ & -.082 & .053 & -1.545 & .123 & 1.067 & $F R 1$ & -.357 & .165 & -2.166 & .034 & 1.282 \\
\hline FR2 & .382 & .061 & 6.273 & .000 & 1.222 & $F R 2$ & .188 & .129 & 1.455 & .150 & 1.439 \\
\hline$F R 3$ & .118 & .080 & 1.465 & .144 & 2.047 & $F R 3$ & .111 & .234 & .474 & .637 & 2.380 \\
\hline FR4 & -.061 & .080 & -.767 & .443 & 2.089 & FR4 & .605 & .250 & 2.425 & .018 & 2.690 \\
\hline
\end{tabular}
$(t$-stat: $p$-value $=.018)$. Linear regression functions have the form:

Table 4. The impact of financial risk indicators on the perception of the future of business according to the criterion

Source: Own research.

Note: Df - Degree of freedom; SS - Sum of Squares; MS - Mean of Square; RC - Regression Coefficient; SE - Standard Error. 
RM2A:

$$
\begin{aligned}
& Y=1.367-0.082 \cdot F R 1+ \\
& +0.382 \cdot F R 2+0.118 \cdot F R 3- \\
& -0.061 \cdot F R 4+\varepsilon_{t},
\end{aligned}
$$

RM2B:

$$
\begin{aligned}
& Y=1.455-0.357 \cdot F R 1+ \\
& +0.188 \cdot F R 2+0.188 \cdot F R 3+ \\
& +0.605 \cdot F R 4+\varepsilon_{t},
\end{aligned}
$$

where UP6 - dependent variable (perception of the future of business); $F R 1, \ldots, F R 4$ - independent variables (financial risk indicators); $\varepsilon_{t}$ - error term.

Multicollinearity was not confirmed for either $R M$ (VIF values are higher than the critical value for both $R M 2 A$ and $R M 2)$. Homoskedasticity was confirmed in both $R M \mathrm{~s}$ (RM2A: Bartlett's test: $p$-value $=.244 ; R M 2 B$ : Bartlett's test: $p$-value $=.189)$. The $S-W$ test confirmed the normal distribution of the deviations of the error terms in both RMs $(R M 2 A$ : S-W test: $p$-value $=.542$; $R M 2 B: S$-W test: $p$-value $=.648)$. The evaluation of scientific hypothesis: $H_{b}$ was accepted for both groups of respondents according to the entrepreneur's experience with business bankruptcy.
The comparison of the impact of personnel risk on the perception of the future of business according to the respondent's experience with the bankruptcy of business is the subject of Table 5 .

RM3B: The results (see Table 5) show that the proposed regression model of the linear relationships of personnel risk indicators to the threat of corporate/business bankruptcy is not statistically significant $(F-$ ratio: $p$-value $=.290)$. Because of the above testing, it is not relevant to sharpen the regression function and verify the random component's assumptions. RM $3 A$ : The results (see Table 5) show that the proposed regression model is statistically significant (F-ratio: $p$-value $=.001)$. The dependence between the company's emotional future and the indicators of strategic risk is moderately positive $(M C C=.240)$. The regression model (with strategic risk indicators) is explained by $4.8 \%$ of the dependent variable's variability. A statistically significant indicator is PER4 ( $t$-stat: $p$-value $=.020$ ). The $R M 3 A$ linear regression function has the form:

RM3A:

\begin{tabular}{|c|c|c|c|c|c|c|c|c|c|c|c|}
\hline \multicolumn{6}{|c|}{ RM3A - No experience with business bankruptcy } & \multicolumn{6}{|c|}{ RM3B - Business bankruptcy experience } \\
\hline MCC & \multicolumn{2}{|c|}{.240} & Adj. $R^{2}$ & \multicolumn{2}{|c|}{.048} & $\mathrm{MCC}$ & \multicolumn{2}{|c|}{.264} & Adj. $R^{2}$ & \multicolumn{2}{|c|}{.015} \\
\hline$R^{2}$ & \multicolumn{2}{|c|}{.058} & SE & \multicolumn{2}{|c|}{1.013} & $R^{2}$ & \multicolumn{2}{|c|}{.070} & SE & \multicolumn{2}{|c|}{1.323} \\
\hline \multicolumn{12}{|c|}{ Verification of the significance of the entire LRM } \\
\hline ANOVA & Df & SS & MS & \multicolumn{2}{|c|}{ F-ratio } & ANOVA & Df & SS & MS & \multicolumn{2}{|c|}{ F-ratio } \\
\hline Regression & 4 & 23.58 & 5.89 & \multicolumn{2}{|c|}{5.774} & Regression & 4 & 8.89 & 2.22 & \multicolumn{2}{|c|}{1.270} \\
\hline Residual & 376 & 385.86 & 1.03 & \multicolumn{2}{|c|}{$p$-value } & Residual & 68 & 119.03 & 1.75 & \multicolumn{2}{|c|}{$p$-value } \\
\hline Total & 380 & 409.44 & & \multicolumn{2}{|c|}{.001} & Total & 72 & 127.92 & & \multicolumn{2}{|c|}{.290} \\
\hline \multicolumn{12}{|c|}{ Statistical significance test } \\
\hline Variables & RC & SE & $t$-stat & $\begin{array}{c}\text { Sign. } \\
\text { ( } p \text {-value) }\end{array}$ & VIF & Variables & RC & SE & $t$-stat & $\begin{array}{c}\text { Sign. } \\
\text { ( } p \text {-value) }\end{array}$ & VIF \\
\hline Intercept & 1.444 & .162 & 8.918 & .000 & - & Intercept & 1.999 & .496 & 4.029 & .000 & \\
\hline PER1 & .025 & .053 & .477 & .634 & 1.385 & PER 1 & .130 & .183 & .711 & .479 & 1.661 \\
\hline PER2 & .080 & .058 & 1.384 & .167 & 1.929 & $P E R 2$ & -.113 & .174 & -.650 & .518 & 1.969 \\
\hline PER3 & .038 & .065 & .590 & .556 & 1.888 & PER3 & -.030 & .180 & -.169 & .866 & 1.666 \\
\hline PER4 & .123 & .052 & 2.340 & .020 & 1.366 & PER 4 & .294 & .160 & 1.838 & .070 & 1.390 \\
\hline
\end{tabular}

$$
\begin{aligned}
& Y=1.444+.025 \cdot P E R 1+ \\
& +0.080 \cdot P E R 2+0.038 \cdot P E R 3+ \\
& +0.123 \cdot P E R 4+\varepsilon_{t},
\end{aligned}
$$

Table 5. The influence of personnel risk indicators on the perception of the future of business according to the criterion

Source: Own research

Note: Df - Degree of freedom; SS - Sum of Squares; MS - Mean of Square; RC - Regression Coefficient; SE - Standard Error. 
where $Y$ - dependent variable (perception of the future of business); PER1, ..., PER4 independent variables (personnel risk indicators); $\varepsilon_{t}-$ error term.

VIF test values did not show the presence of multicollinearity in the independent variables. Homoscedasticity was confirmed in $R M$ (Bartlett's test: $p$-value $=.317$ ). The normal distribution of the error terms' deviations was confirmed by the S-W test (S-W test: $p$-value $=.163)$. The evaluation of scientific hypothesis: $H_{a}$ was accepted for both groups of respondents according to the entrepreneur's experience with business bankruptcy.

\section{DISCUSSION}

The experience with the bankruptcy of the respondent is not significant in the perception of the most important indicator of market risk. It is the adequacy of sales of services and products for both groups of respondents. Both groups do not consider the impact of innovative ways of acquiring new markets on the future to be significant. Conversely, according to respondents who do not experience bankruptcy $(n=381)$, there is no significant impact of competition as a motivating factor for the respondent ( $t$-stat: $p$-value $=.892)$ and according to respondents who experience bankruptcy $(n=73)$, there is a significant impact of competition as a motivating factor for the respondent $(t$-stat: $p$-value $=.020)$.

The respondent's experience with bankruptcy is significant in the impact of financial risk indicators on the future. According to respondents who have no experience with bankruptcy $(n=381)$, there is a significant impact of the perception of the financial performance of the company/business ( $t$-stat: $p$-value $=$ $=000$ ) on the future as the only indicator of financial risk. According to respondents who have experi- enced bankruptcy $(n=73)$, the perception of financial risk is part of everyday life ( $t$-stat: $p$-value $=.034$ ). Moreover, respondents' ability to properly manage financial risk ( $t$-stat: $p$-value $=.018)$ is significant for the future of the enterprise/business. The ability of respondents to properly manage financial risk $(\beta=$ .605) has a more significant positive impact on the future of the company/business than the perception of financial risk as part of everyday life $(\beta=-.357)$. The negative value of a statistically significant indicator of financial risk can be explained by the fact that the presence of financial risk as a part of everyday life is already so obvious for the respondent that it is underestimated.

The respondent experience with bankruptcy is significant in the impact of personnel risk indicators on the future. According to respondents who have no experience with bankruptcy $(n=381)$, the future of the company/business is significantly influenced by the employees' efforts to increase performance $(\beta=.123)$. According to the respondents who have experienced bankruptcy ( $n=73)$, there is no significant impact of any indicator of personnel risk ( $t$-stat: $p$-value $>0.05)$ on the future of the company.

The research results are essential for potential, active entrepreneurs who face the fear of failure. Equally important are the findings for entrepreneurs who already have experience with bankruptcy. Failure is not an obstacle to doing business, and our results show that it is part of the business journey. Existing business research underlines the importance of passion, optimism, and the need to achieve business motivation (Cardon, Wincent, Singh, \& Drnovsek, 2009; Hmieleski \& Baron, 2009). Fear of failure also affects business motivation but not always negatively. In many cases, this may be related to the decision to take an even stronger approach. Besides, it also has implications for business performance and well-being (Cacciotti, Hayton, Mitchell, \& Giazitzoglu, 2016).

\section{CONCLUSION}

The article aimed to identify differences in the perception of the most significant business risks and their impact on the future of business concerning the entrepreneur's experience with business bankruptcy.

Entrepreneurs who have no experience with bankruptcy perceive the direct impact of increasing employee performance on the company's future. On the other hand, entrepreneurs who have gone through business decline do not perceive the impact of personnel risk indicators on the business's perceived future. There are 
also differences between entrepreneurs in attitudes to the effect of personnel risk. Entrepreneurs who have no experience with bankruptcy perceive the direct impact of increasing employee performance on the company's future. On the other hand, entrepreneurs who have gone through business decline do not perceive indicators of personnel risk, such as employee turnover, employee error rate, or increasing employee performance.

Despite a representative sample of 454 SMEs, in the future, it would be necessary to re-verify the attitudes of entrepreneurs in the business environment in the Czech Republic. This is owing to the verification of the achieved results and the ongoing COVID-19 crisis. The nature of research, which deals with the attitudes of entrepreneurs from only one Central European country, is also limiting. The results are important, especially for SMEs themselves, and for state and non-profit institutions in setting up incentives to raise the quality of the business environment for SMEs.

The authors want to compare our findings regarding the influence of business risks on the perception of SMEs' future in the Czech Republic with other countries of the Visegrad Group (V4). Therefore, they are currently starting to work with academic staff from partner universities in Hungary, Poland, and the Slovak Republic to obtain a relevant sample of respondents.

\section{AUTHOR CONTRIBUTIONS}

Conceptualization: Aleksandr Ključnikov, Jiří Polách.

Data curation: Ján Dvorský.

Formal analysis: Ján Dvorský.

Investigation: Aleksandr Ključnikov.

Methodology: Ján Dvorský, Jiří Polách.

Project administration: Ján Dvorský.

Supervision: Aleksandr Ključnikov.

Validation: Ján Dvorský.

Visualization: Aleksandr Ključnikov, Jiří Polách.

Writing - original draft: Ján Dvorský.

Writing - review \& editing: Aleksandr Ključnikov.

\section{REFERENCES}

1. Aidis, R., Estrin, S., \& Mickiewicz, T. M. (2012). Size matters: Entrepreneurial entry and government. Small Business Economics, 39(1), 119-139. https:// dx.doi.org/10.1007/s11187-0109299-y

2. Ajaz Khan, K., Çera, G., \& Nétek, V. (2019). Perception of the Selected Business Environment Aspects by Service Firms. Journal of Tourism and Services, 10(19), 111-127. https:// doi.org/10.29036/jots.v10i19.115

3. Ajilchi, B., \& Kargar, F. R. (2015). Prediction of job stress among employees through the dimensions of time management skills by managers. Indian Journal of Science and Technology, 8(34), 1-7. https:// dx.doi.org/10.17485/ijst/2015/ v8i34/73334
4. Alzhrani, A. M. (2020). Outsourcing human resource functions and their impact on organizational performance. International Journal of Industrial and Business Management, 4(18), 1-16. Retrieved from https://escipub.com/ ijibm-2020-01-2305/

5. Anwar ul Haq, M., Usman, M., Hussain, N., \& Anjum, Z. (2014). Entrepreneurial activity in China and Pakistan: A GEM data evidence. Journal of Entrepreneurship in Emerging Economies, 6(2), 179-193. https:// dx.doi.org/10.1108/JEEE-03-20140006

6. Belas, J., Dvorsky, J., Kozubikova, L., \& Cepel, M. (2019). Important factors of SMEs entrepreneurial orientation. Ikonomicheski Izsledvania, 28(3), 165-179. Retrieved from https://www. researchgate.net/publication/337059878_Important_factors_of_SMEs_entrepreneurial_orientation

7. Benzing, C., Chu, H. M., \& Kara, O. (2009). Entrepreneurs in turkey: A factor analysis of motivations, success factors, and problems. Journal of Small Business Management, 47(1), 58-91. https://dx.doi.org/10.1111/j.1540627X.2008.00262.X

8. Bolshakov, A., \& Chincarini, L. B. (2020). Manager skill and portfolio size with respect to a benchmark. European Financial Management, 26(1), 176-197. 
https://dx.doi.org/10.1111/ eufm. 12210

9. Breslow, N. (1990). Tests of hypotheses in over dispersed poisson regression and other quasi-likelihood models. Journal of the American Statistical Association, 85(410), 565-571. https://doi.org/10.1080/01621459.19 90.10476236

10. Brozyna, J., Mentel, G., \& Pisula, T. (2016). Statistical methods of the bankruptcy prediction in the logistics sector in Poland and Slovakia. Transformations in Business and Economics, 15(1), 93-114. Retrieved from https:// www.researchgate.net/publication/301343044_Statistical_methods_of_the_bankruptcy_prediction_in_the_logistics_sector_in_Poland_and_Slovakia

11. Cacciotti, G., Hayton, J. C., Mitchell, J. R., \& Giazitzoglu, A. (2016). A reconceptualization of fear of failure in entrepreneurship. Journal of Business Venturing, 31(3), 302-325. https://dx.doi.org/10.1016/j.jbusvent.2016.02.002

12. Cardon, M. S., Wincent, J., Singh, J., \& Drnovsek, M. (2009). The nature and experience of entrepreneurial passion. Academy of Management Review, 34(3), 511532. https://dx.doi.org/10.5465/ AMR.2009.40633190

13. Carter, R., \& Van Auken, H. (2006) Small firm bankruptcy. Journal of Small Business Management, 44(4), 493-512. https://dx.doi.org/10.1111/ j.1540-627X.2006.00187.x

14. Çera, G., Belas, J., \& Zapletalikova, E. (2019). Explaining business failure through determinist and voluntarist perspectives. Serbian Journal of Management, 14(2), 257-275. https://dx.doi.org/10.5937/ sjm14-23348

15. de Waal, D. J. (1977). Asymptotic distributions for the elementary symmetric functions of two matrices under the assumption of linearity. Journal of Multivariate Analysis, 7(1), 223-228. http://dx.doi. org/10.1016/0047-259X(77)90042-2

16. Durica, M., Valaskova, K., \& Janoskova, K. (2019). Logit business failure prediction in $\mathrm{V} 4$ countries. Engineering Management in Production and Services, 11(4),
54-64. https://dx.doi.org/10.2478/ emj-2019-0033

17. Dvorský, J., Petraková, Z., Çera, G., \& Folvarčná, A. (2019a). Important factors for the entrepreneurship in central Europe. Innovative Marketing, 15(2), 7183. https://dx.doi.org/10.21511/ im.15(2).2019.06

18. Dvorský, J., Petráková, Z., \& Polách, J. (2019b). Assessing the Market, Financial, and Economic Risk Sources by Czech and Slovak SMEs. International Journal of Entrepreneurial Knowledge, 7(2), 30-40. https://doi.org/10.37335/ijek. v7i2.91

19. Eklund, J., Levratto, N., \& Ramello, G. B. (2020). Entrepreneurship and failure: Two sides of the same coin? Small Business Economics, 54(2), 373-382. https:// dx.doi.org/10.1007/s11187-0180039-z

20. Estrin, S., Mickiewicz, T., \& Rebmann, A. (2017). Prospect theory and the effects of bankruptcy laws on entrepreneurial aspirations. Small Business Economics, 48(4), 977-997. https:// dx.doi.org/10.1007/s11187-0169810-1

21. Fabuš, M. (2017). Current development of business environment in Slovakia and Czech Republic. Entrepreneurship and Sustainability Issues, 5(1), 127 137. https://dx.doi.org/10.9770/ jesi.2017.5.1(10)

22. Goodman, L. A. (1970). The multivariate analysis of qualitative data: Interactions among multiple classifications. Journal of the American Statistical Association, 65(329), 226-256. https://dx.doi.org/10.1080/0162145 9.1970.10481076

23. Hair, J. F., Anderson, R. E., Babin, B. J., \& Black, W. C. (2010). Multivariate data analysis: A global perspective (7th ed.). Upper Saddle River, NJ: Pearson Prentice Hall.

24. Hanzaee, K. H., Ghalandari, K., \& Norouzi, A. (2011). The effect of brand social power dimensions on purchasing decision based on Iranian customers' subjective readiness. World Applied Sciences Journal, 13(5), 1197-1208. Retrieved from https://www.researchgate.net/
publication/282282958_The_effect_of_brand_social_power_dimensions_on_purchasing_decision_based_on_iranian_customers'_subjective_readiness

25. Havierniková, K., \& Kordoš, M. (2019). Selected risks perceived by SMEs related to sustainable entrepreneurship in case of engagement into cluster cooperation. Entrepreneurship and Sustainability Issues, 6(4), 16801693. https://dx.doi.org/10.9770/ jesi.2019.6.4(9)

26. He, H. K., Li, C. S., Lin, Z., \& Liang, S. (2019). Creating a high-performance exhibitor team: A temporary-organization perspective. International Journal of Hospitality Management, 81, 21-29. https://dx.doi.org/10.1016/j. ijhm.2019.02.009

27. Hemakumar, M. N. (2020). Impact of training and development on employee retention at leading food and agri business company. International Journal of Advanced Science and Technology, 29(3s), 1170-1175. Retrieved from http://sersc.org/journals/index.php/ IJAST/article/view/5975

28. Hmieleski, K., \& Baron, R. (2009). Entrepreneurs' optimism and new venture performance: A social cognitive perspective. Academy of Management Journal, 52(3), 473488. https://dx.doi.org/10.5465/ AMJ.2009.41330755

29. Hudakova, M., \& Masar, M. (2018) The assessment of key business risks for SMEs in Slovakia and their comparison with other EU countries. Entrepreneurial Business and Economics Review, 6(4), 145160. https://dx.doi.org/10.15678/ EBER.2018.060408

30. Hudakova, M., Masar, M., Luskova M., \& Patak, M. R. (2018). The Dependence of Perceived Business Risks on the Size of SMEs. Journal of Competitiveness, 10(4), 5469. https://doi.org/10.7441/ joc.2018.04.04

31. Hyder, S., \& Lussier, R. N. (2016). Why businesses succeed or fail: A study on small businesses in Pakistan. Journal of Entrepreneurship in Emerging Economies, 8(1), 82-100. https:// 
dx.doi.org/10.1108/JEEE-03-20150020

32. Inkon, K. (2019). A cross-sectional study on the relationship between business plan, entrepreneur type, development stage and profitability of US SMEs. Academy of Entrepreneurship Journal, 25(1). Retrieved from https://www. abacademies.org/articles/a-crosssectional-study-on-the-relationship between-business-plan-entrepreneur-type-development-stage-andprofitability-of-us-smes-7985.html

33. James, A. T. (1964). Distribution of matrix variates and latent roots derived from normal samples. The Annals of Mathematical Statistics, 35(2), 475-501. Retrieved from https://projecteuclid.org/ euclid.aoms/1177703550

34. Kliestik, T., Misankova, M., Valaskova, K., \& Svabova, L. (2018). Bankruptcy prevention: new effort to reflect on legal and social changes. Science and Engineering Ethics, 24(2), 791-803. https://dx.doi.org/10.1007/ s11948-017-9912-4

35. Kücher, A., \& Feldbauer-

Durstmüller, B. (2019).

Organizational failure and decline A bibliometric study of the scientific frontend. Journal of Business Research, 98, 503-516. https://dx.doi. org/10.1016/j.jbusres.2018.05.017

36. Lancaster, H. O., \& Hamdan, M. A. (1964). Estimation of the correlation coefficient in contingency tables with possibly nonmetrical characters. Psychometrica, 29, 383-391. http://dx.doi.org/10.1007/ BF02289604

37. Lenz, K. M. (2019). Communication skills and teaming are a project manager's best tools. Paper presented at the Proceedings ACM SIGUCCS User Services Conference (pp. 36-39). https://dx.doi. org/10.1145/3347709.3357219

38. Liao, D., \& Valliant, R. (2012). Variance inflation factors in the analysis of complex survey data. Survey Methodology, 38(1), 53-62. Retrieved form https://pdfs.semanticscholar.org/172a/462f01ab8947d7f5 621468e35f64d2998199.pdf

39. Lu, Z., Gozgor, G., Huang, M., \& Lau, C. K. M. (2020). The Impact of Geopolitical Risks on Financial Development: Evidence from Emerging Markets. Journal of Competitiveness, 12(1), 93107. https://doi.org/10.7441/ joc. 2020.01 .06

40. Murnieks, C. Y., Klotz, A C., \& Shepherd, D. A. (2020). Entrepreneurial motivation: A review of the literature and an agenda for future research. Journal of Organizational Behavior, 41(2), 115-143. https://dx.doi.org/10.1002/ job. 2374

41. Nava, N., Di Matteo, T., \& Aste, T. (2018). Financial time series forecasting using empirical mode decomposition and support vector regression. Risks, 6(1), 7. https://doi. org/10.3390/risks6010007

42. Newcombe, R. G. (1998). Interval estimation for the difference between independent proportions: Comparison of eleven methods. Statistics in Medicine, 17(8), 873-890. https:// dx.doi.org/10.1002/(SICI)10970258(19980430)17:8<873::AIDSIM779>3.0.CO;2-I

43. Qin, J., \& Lawless, J. (1995). Estimating equations, empirical likelihood and constraints on parameters. Canadian Journal of Statistics, 23(2), 145-159. https:// dx.doi.org/10.2307/3315441

44. Ranasinghe, R. (2019). Antecedents of Job Performance of Tourism Graduates: Evidence from State University-Graduated Employees in Sri Lanka. Journal of Tourism and Services, 10(18), 16-34. https://doi. org/10.29036/jots.v10i18.83

45. Salmerón, R., García, C. B., \& García, J. (2018). Variance inflation factor and condition number in multiple linear regression. Journal of Statistical Computation and Simulation, 88(12), 2365-2384. http:// dx.doi.org/10.1080/00949655.2018 .1463376

46. Santisteban, J., \& Mauricio, D. (2017). Systematic literature review of critical success factors of information technology startups. Academy of Entrepreneurship Journal, 23(2), 1-23. Retrieved from https://www. abacademies.org/articles/systematic-literature-review-of-criticalsuccess-factors-of-informationtechnology-startups-6638.html

47. Singh, As., \& Singh, Aj. (2020). Organizational change and employee job satisfaction in tourism sector. Test Engineering and Management, 82(1-2), 15587-15592. Retrieved from http://testmagzine. biz/index.php/testmagzine/article/ view/3283

48. Snedecor, G. W., \& Cochran, W. G. (1989). Statistical Methods (8th ed.). Iowa State University Press.

49. Spanos, A., \& McGuirk, A. (2002). The problem of nearmulticollinearity revisited: Erratic vs systematic volatility. Journal of Econometrics, 108(2), 365-393. http://dx.doi.org/10.1016/S03044076(01)00144-0

50. Stepanova, P. (2019). Krach nejvíc ohrožuje firmy z okolí Brna a Prahy. Bisnode. Retrieved from https:// www.bisnode.cz/o-bisnode/o-nas/ novinky/krach-nejvic-ohrozujefirmy-z-okoli-brna-a-prahy/

51. Stewart, G. W. (1987). Collinearity and least squares regression. Statistical Science, 2(1), 68-84. http://dx.doi.org/10.1214/ ss/1177013439

52. Tipu, S. A. A. (2019). Business plan competitions in developed and emerging economies: What do we still need to know? Journal of Entrepreneurship in Emerging Economies, 11(1), 81-97. https:// dx.doi.org/10.1108/JEEE-12-20170102

53. Valaskova, K., Kliestik, T., \& Kovacova, M. (2018). Management of financial risks in Slovak enterprises using regression analysis. Oeconomia Copernicana, 9(1), 105-121. https://doi.org/10.24136/ oc. 2018.006

54. Yan, J., \& Yan, L. (2016). Individual entrepreneurship, collective entrepreneurship and innovation in small business: An empirical study. International Entrepreneurship and Management Journal, 12(4), 1053-1077. https:// dx.doi.org/10.1007/s11365-0150380-5

55. Zheng, M., \& Yu, W. (2015). Linear regression analysis with inequality constraints on the regression parameters via empirical likelihood. Journal of Statistical Computation and Simulation, 85(9), 1782-1792. http://dx.doi.org/10.1080 /00949655.2014.902459 